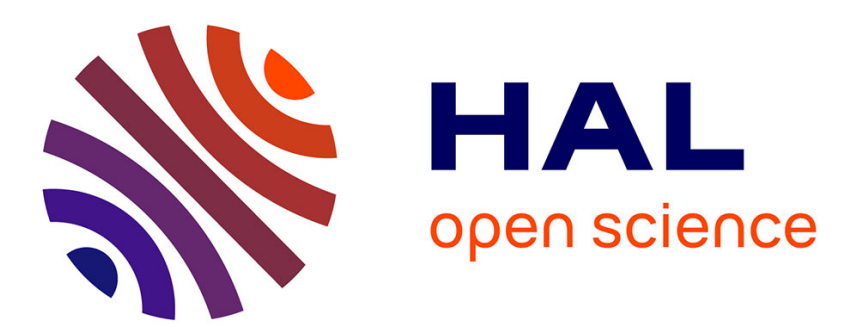

\title{
Glass ceramics and mineral materials for the immobilization of lead and cadmium
}

Katerina Krausova, Laurent Gautron, Aurélie Karnis, Gilles Catillon, Stephan Borensztajn

\section{- To cite this version:}

Katerina Krausova, Laurent Gautron, Aurélie Karnis, Gilles Catillon, Stephan Borensztajn. Glass ceramics and mineral materials for the immobilization of lead and cadmium. Ceramics International, 2016, 42 (7), pp.8779-8788. 10.1016/j.ceramint.2016.02.119 . hal-01632320

\section{HAL Id: hal-01632320 https://hal.science/hal-01632320}

Submitted on 10 Nov 2017

HAL is a multi-disciplinary open access archive for the deposit and dissemination of scientific research documents, whether they are published or not. The documents may come from teaching and research institutions in France or abroad, or from public or private research centers.
L'archive ouverte pluridisciplinaire HAL, est destinée au dépôt et à la diffusion de documents scientifiques de niveau recherche, publiés ou non, émanant des établissements d'enseignement et de recherche français ou étrangers, des laboratoires publics ou privés. 


\title{
Glass ceramics and mineral materials for the immobilization of lead and cadmium
}

\author{
Katerina Krausova ${ }^{1 *}$, Laurent Gautron ${ }^{1}$, Aurélie Karnis ${ }^{1}$, Gilles Catillon ${ }^{1}$ and Stephan Borenstajn ${ }^{2}$
}

\author{
${ }^{1}$ Laboratoire Géomateriaux et Environnement (LGE, EA 4508), 5 Bd Descartes University Paris-Est 77454 \\ Marne-la-Vallée (UPEM), Champs-sur-Marne, France \\ ${ }^{2}$ Laboratoire Interfaces et Systèmes Electrochimiques (LISE), University Pierre et Marie Curie (UPMC), \\ Paris, France
}

*Corresponding author; E-mail address: krausovak@seznam.cz , tel.: +33 149329054

\section{Abstract}

Waste management is one of the major global environmental issues. Incineration is an efficient treatment since it offers both a reduction of mass and volume and a possibility of energy recovery. One of the problems of incineration is the production of fly ash which is considered as hazardous waste with obligation of final disposal into a specific landfill.

The objective of the present study is to investigate glass ceramics and sintered ceramics as new mineral materials for a sustainable immobilization and possible recycling of these incineration wastes. Toxic elements can be incorporated into crystals embedded in a glass matrix which has a function of the second barrier, or in highly resistant crystalline structure in a sintered ceramic. Based upon cations size considerations, this study is focused on Ca-rich or Ba-bearing minerals as possible hosts of lead and cadmium.

Promising results have been obtained for $\mathrm{CaMgSi}_{2} \mathrm{O}_{6}$ diopside-bearing glass ceramics and sintered $\mathrm{Ba}_{1.5} \mathrm{Mg}_{1.5} \mathrm{Ti}_{6.5} \mathrm{O}_{16}$ hollandite, both in terms of toxic elements incorporation and of chemical resistance.

Keywords: A. Lead, Cadmium, B. Glass ceramics; C. Sintering; D. Microstructure; E: Sustainable. 


\section{Introduction}

All over the world, technical and industrial evolution gives rise to increasing amount of wastes from all domains of human activities. The production of wastes is strongly related to the degree of development of a country, and we can expect an intensification of this production, for example in developing countries like China or India.

The increasing Municipal Solid Waste (MSW) generation is a problem ranging to global concern. Among various MSW treatment methods, incineration is a technology, which may provide an efficient and environmental friendly solution. Compared to landfill deposit, the process of incineration has several advantages, as a major volume reduction, a possible caloric recovering for electricity or heat production and a destruction of pathogenic organisms. The problem of this treatment is the production of fly ash (FA) $F$ and bottom ash (BA) solid residues. FA may contain large amounts of toxic metal compounds (lead, cadmium, mercury etc.) [1] and is considered as a hazardous waste with obligation of final disposal into specific landfills. Bottom ash is not classified as a hazardous waste because of its less dangerous composition and then it can be used as construction materials for instance as feed stocks of road building.

With the aim of sustainable development and also to make incineration more attractive, the FA must be treated into inert material which is safe for construction use. Goel et al. [2] identified nine different options for the treatment of MSW Incinerated (MSWI) fly ash. Two of these methods involve thermal treatment with high temperatures $\left(>1000^{\circ} \mathrm{C}\right)$ in order to produce glass ceramics and sintered ceramics. These two materials should display an efficient and sustainable incorporation of toxic heavy metals which then are less available for leaching.

The aim of this study is to investigate glass ceramics and sintered ceramics with mineral phases, rich in calcium, barium and/or magnesium for the immobilization of heavy metals in municipal solid waste incinerated ashes, with a focus on lead and cadmium. According to Goldschmidt rules [3], calcium and barium cations in crystal structures seem to be capable of being relatively easily substituted by cations of $\mathrm{Pb}$ and/or $\mathrm{Cd}$. 
Glass ceramics are materials where toxic elements can be incorporated into crystals which are embedded into a glass matrix then generating a double barrier protection for the environment. Such protection concept was also envisaged for the immobilization of highly radioactive waste such as actinides [4,5]. As this matrix contains both glass and ceramic, it offers good physical and chemical properties impossible to obtain only with glass or only with ceramic. Many studies $[6,7,8,9,10]$ have investigated the possibility of producing glass ceramics by devitrification of the raw materials from MSW incinerator. Successful results were reported for $\mathrm{FA}$ with addition of $\mathrm{LiO}_{2}$ [7], $\mathrm{FA}$ with additions of glass cullet and feldspar [8] or with addition of $\mathrm{TiO}_{2}$ [9]. They all reported that glass ceramics display good mechanical and physical properties. With a simple addition of commercial oxides, it could be possible to achieve a resistant mineral phase with heavy metals incorporated inside their crystallographic sites. A promising crystal structure having a strong fixing capacity for significant quantities of heavy metals such as lead $(\mathrm{Pb})$ and cadmium $(\mathrm{Cd})$ was evaluated to be diopside phase within the Ca-Mg-Si-O system $[9,11]$. Diopside has a monoclinic crystal structure which can be described as a succession of parallel layers of $\mathrm{SiO}_{4}$ tetraedra alternating with layers of both $\mathrm{MgO}_{6}$ octaedra and $\mathrm{CaO}_{8}$ polyedra. As the $\mathrm{MSWI}$ ashes used in the present study, are rich in $\mathrm{Ca}(47.2 \mathrm{wt} \% \mathrm{CaO}), \mathrm{Al}\left(13.7 \mathrm{wt} \% \mathrm{Al}_{2} \mathrm{O}_{3}\right)$ and $\mathrm{Si}\left(27.9 \mathrm{wt} \% \mathrm{SiO}_{2}\right)$, it could be easy and relatively cheap to produce diopside phase from theses wastes. We also evaluated the $\mathrm{Pb}-\mathrm{Cd}$ incorporation capacity of diopside, by addition of $12 \mathrm{wt} \% \mathrm{PbO}$ and $12 \mathrm{wt} \% \mathrm{CdO}$ into the initial composition.

The second considered material is a sintered ceramic which is known to be a material with high mechanical and chemical resistance. Sintered ceramics were successfully investigated for radioactive waste immobilization $[12,13,14]$. A promising sintered ceramic in the system Ba-Mg-Ti-O is shown to have a composition $\mathrm{Ba}_{x} \mathrm{Mg}_{x} \mathrm{Ti}_{8-\mathrm{x}} \mathrm{O}_{16}$, with $\mathrm{x}=1.1$ [15]. This composition corresponds to a hollandite phase, which is expected to be able to host voluminous cations in its relatively opened structure characterized by a framework of $(\mathrm{M}, \mathrm{Ti}) \mathrm{O}_{6}$ octahedra $(\mathrm{M}=$ trivalent or divalent cations) wherein there are sorts of tunnels with sizes corresponding to large ionic radii of elements like $\mathrm{Ba}^{2+}[16,17,18]$. Then these barium sites are expected to host voluminous elements like $\mathrm{Pb}$ or $\mathrm{Cd}$ (for example, the ionic radii difference is $8 \%$ between $\mathrm{Ba}$ and $\mathrm{Pb}$ in coordination 10 , after Shannon [19]). Similarly previous studies $[17,18]$ envisaged that such hollandite structure could incorporate big radioactive $\mathrm{Cs}^{+}$cations. 
All waste bearing matrices were observed and analyzed by X-Ray Diffraction (XRD) and Scanning Electron Microscopy (SEM) coupled to Energy Dispersive X-Ray microanalysis (EDX). Physical and chemical properties such as density, porosity, water absorption and hardness were determined for each matrix. Sustainability of these waste-bearing materials was estimated through leaching experiments of the Toxicity Characteristic Leaching Procedure (TCLP).

\section{Materials and experimental procedure}

\subsection{Synthesis of glass ceramic and sintered ceramic}

Two types of samples have been investigated. Firstly we focused on glass ceramic matrix based on diopside phase, and secondly we worked on sintered ceramic with hollandite as a principal mineral phase. All the samples synthetized were doped with lead and cadmium in order to evaluate the immobilization efficiency.

Powders used for glass ceramics and sintered ceramics were $\mathrm{SiO}_{2}$ (purity $>99,5 \%$ ), $\mathrm{CaCO}_{3}$ (purity $>99,0 \%$ ), $\mathrm{Al}_{2} \mathrm{O}_{3}$ (purity $>99,0 \%$ ), $\mathrm{MgO}$ (purity >96,0\%), $\mathrm{TiO}_{2}$ (purity $>99,0 \%$ ), $\mathrm{Ba}_{2} \mathrm{CO}_{3}$ (purity > 99,8\%), $\mathrm{PbO}$ (purity $>99,9 \%$ ) and $\mathrm{CdO}$ (purity $>99,9 \%$ ). The mixtures ( 2g) were transformed into pellets (about $1 \mathrm{~cm}$ in diameter) using a hydraulic press machine under 250-300 bars during 120 seconds at room temperature: this operation is expected to prevent possible volatilization of heavy metals. Moreover, the mixture was synthetized in a platinum-rhodium crucible with a special top for prevention of volatilization.

For each type of matrix, we have synthesized one green sample (GC-GS and SC-GS are Glass Ceramic Green Sample and Sintered Ceramic Green Sample respectively) and one with addition of lead (12 wt\%) and cadmium (12 wt\%) in form of oxides (named GC-CdPb and SC-CdPb). The composition of the samples and the cycles of heat treatments are given in Table 1.

Glass ceramics samples are preheated in an electric laboratory furnace at $900^{\circ} \mathrm{C}$ for 60 min with two objectives: evaporation of ethanol used during milling and decarbonation. The mix is then melted for $20 \mathrm{~min}$ at $1500^{\circ} \mathrm{C}$, which is the right temperature to obtain highly homogenous molten glassy mixture after quenching. The weight loss compared to the initial composition weight before heating 
(independently from decarbonation), was below $8 \mathrm{wt} \%$. The transparent glass obtained is milled in an agate mortar into a homogeneous fine powder (the particle size distribution was below 100 microns) in order to get a more efficient devitrification. Sample of this powder was analyzed by XRD to confirm its amorphous character. For the devitrification process to get the glass ceramic, the glass powder is heated under isothermal conditions for $20 \mathrm{~min}$ at $1050^{\circ} \mathrm{C}$ with a heating ramp at a rate of $10^{\circ} \mathrm{C} / \mathrm{min}$ and a cooling ramp to room temperature at a rate of $8.5^{\circ} \mathrm{C} / \mathrm{min}$. This heat treatment follows the previous results from Barbieri et al. (2002) [11], as they evidenced optimum crystal nucleation and growth temperatures of $750^{\circ} \mathrm{C}$ and $910^{\circ} \mathrm{C}$ respectively: we decided to rise up the temperature to $1050^{\circ} \mathrm{C}$ directly, then with a short bearing. Then nucleation and growth stages were combined while increasing temperature with the objective to speed up the heating process in order to limit the volatilization effects.

Sintered ceramics are synthesized by blending and milling oxides until we get a homogeneous fine powder. The sample is then heated in an electric furnace with a rate of $4.2^{\circ} \mathrm{C} / \mathrm{min}$ up to $1380^{\circ} \mathrm{C}$ as indicated in a previous study from Badev (2008) [15], in order to obtain the hollandite phase with the desired structure, and kept at this temperature for 3 hours. The color of the sample with a hollandite starting composition, changed into yellow orange after sintering: it is expected that oxidized titanium may give such color to the sample when heated. During this synthesis, we observed a very small loss of weight (about 2 wt\% difference from the weight before heat treatment): in spite of a careful procedure, it is expected that a limited amount of $\mathrm{PbO}$ and/or $\mathrm{CdO}$ is lost by volatilization.

\subsection{Characterization of samples}

The interpretation and identification of crystalline phases were realized by X-Ray Diffraction (XRD) using a diffractometer D8 ADVANCE BRUKER set up in the Bragg-Brentano geometry and using a copper anode. Cu-Ka radiation ( $\lambda=1.540598 \AA$ ) produced at $40 \mathrm{kV}$ scanned the diffraction angles $(2 \theta)$ in a range of $5-80^{\circ}$ with step size of $0.02^{\circ}$ using a count time of 5 seconds per step. Crystalline phases are identified by comparing the intensities and positions of Bragg peaks in the experimental diffractograms 
with standards listed in Mincryst data files or compiled by the International Centre for Diffraction Data (ICDD).

Microstructural characteristics and chemical compositions were identified by Scanning Electron Microscopy (SEM), with a field emission gun microscope ZEISS SUPRA 55V with GEMINI technology integrated and equipped with an Energy Dispersive X-ray microanalysis (EDX) system X Flash 4010 from BRUKER. For SEM analyses, samples were embedded into epoxy resin and polished with sandpaper and diamond-based pastes (with decreasing diameters $d=6,3$ and $1 \mu \mathrm{m}$ as polishing proceeds). The objective of a fine polishing is to minimize errors related to surface roughness, especially for chemical microanalyses. All samples were then carbon coated in order to avoid charges accumulation on samples surfaces which lowers the quality of SEM images. The proportions of the different phases observed in the samples, were determined by calculating the percentage of pixels representation of each color observed on SEM images. It must be assumed that the surface layer of the sample is representative for the whole sample body. The chemical formula of each observed phase was determined from relative atomic mass and mole proportions obtained by EDX spectrometry.

To evaluate and quantify the environmental risk of our new matrices, standard leaching tests of Toxicity Characteristic Leaching Procedure (TCLP) were performed on the samples containing heavy metals. The samples were placed in capped polyethylene tubes and plunged into a solution of glacial acetic acid $\left(\mathrm{CH}_{3} \mathrm{CH}_{2} \mathrm{OOH}\right)$ and deionized water with an initial pH of $2.88 \pm 0.05$ and with a liquid to solid weight ratio of $20(\mathrm{~L} / \mathrm{S}=20)$. For all tests, the temperature was $25^{\circ} \mathrm{C}$. The tubes were tightly closed and agitated at $30 \mathrm{rpm}$ for $20 \mathrm{~h}$. The resultant solutions were filtered through a $20 \mu \mathrm{m}$ paper filters and the concentrations of heavy metals in the leachates were determined by using Inductively Coupled PlasmaAtomic Emission Spectrometry (ICP-AES) SPS 7800 from Seiko Instruments Inc. After leaching, the samples were observed and analyzed by SEM with EDX.

Electronic densitometer SD 200L from Elektron Tek was used to examine physical properties as density, porosity and water absorption while hardness was evaluated through the Mohs scale.

\section{Results and interpretations}




\subsection{Microstructural characterization (XRD, SEM-EDX)}

\subsubsection{Glass ceramics}

The XRD analysis clearly shows that several phases are present in the glass ceramics and that these samples are semi-amorphous. Figure 1 presents the XRD patterns of GC-GS and GC-CdPb. GC-GS displays the following mineral phases: diopside $\left[\mathrm{CaMgSi}_{2} \mathrm{O}_{6}\right]$, wollastonite $\left[\mathrm{CaSiO}_{3}\right]$, anorthite $\left[\mathrm{CaAl}_{2} \mathrm{Si}_{2} \mathrm{O}_{8}\right]$ and also augite $\left[\mathrm{Ca}(\mathrm{Mg}, \mathrm{Ti}, \mathrm{Al})(\mathrm{Si}, \mathrm{Al})_{2} \mathrm{O}_{6}\right]$. The sample with addition of heavy metals (GC-CdPb) displays the same mineral phases and in addition forsterite $\left[\mathrm{Mg}_{2} \mathrm{SiO}_{4}\right]$. Note that the two XRD patterns present similar shape, except near $30^{\circ}$, where two peaks of GC-GS turned into three peaks in GC-CdPb.

The influence of heavy metals addition is evidenced by changes in Bragg peaks intensities. While the highest diffraction peak of the sample GC-CdPb displays an intensity of about 1100 , the same peak of the sample GC-GS has intensity close to 4000 . It seems that the addition of heavy metals could reduce the crystallinity of the sample and could make the crystal growth even more difficult. Then the addition of heavy metals like $\mathrm{Pb}$ or $\mathrm{Cd}$ would have a strong influence on the crystal-growth process.

SEM microstructural observations and EDX chemical analyses gave the exact composition of each mineral phase (see Table 2), heavy metals distribution and their partitioning. The SEM image of GC$\mathrm{CdPb}$ (Figure 2) shows three different contrasts, which were chemically analyzed by EDX. The white area (labelled with "1" on Figure 2) appears with non-geometric shape and it is expected to correspond to the amorphous matrix. This part is characterized by large amounts of heavy metals especially lead, with up to $52.5 \mathrm{wt} \%$ of $\mathrm{PbO}$ and $3.5 \mathrm{wt} \%$ of $\mathrm{CdO}$ (then $49 \mathrm{wt} \% \mathrm{~Pb}$ and about $3 \mathrm{wt} \% \mathrm{Cd}$ ). These parts are also rich in $\mathrm{SiO}_{2}$.

The grey phase (labelled "2" on Figure 2) is rich in $\mathrm{SiO}_{2}, \mathrm{MgO}$ and $\mathrm{CaO}$. The composition of this phase could correspond to the diopside phase $\left[\mathrm{CaMgSi}_{2} \mathrm{O}_{6}\right]$ with $6.25 \mathrm{wt} \%$ of $\mathrm{CdO}(5 \mathrm{wt} \% \mathrm{Cd})$ and 1.75 $\mathrm{wt} \%$ of $\mathrm{PbO}(1.6 \mathrm{wt} \% \mathrm{~Pb})$ (Figure 3). Such result is in correlation with XRD analyses which revealed the presence of diopside as well. Based upon steric considerations from Pauling [20] and Goldschmidt rules [3], it is expected that cadmium and lead are probably incorporated into the calcium site, then with the following formula:

$$
\left(\mathrm{Ca}_{0.69} \mathrm{Cd}_{0.1} \mathrm{~Pb}_{0.02} \mathrm{Mg}_{0.1} \mathrm{Al}_{0.09}\right) \Sigma_{1.0} \mathrm{Mg}\left(\mathrm{Si}_{0.92} \mathrm{Al}_{0.08}\right) \Sigma_{2.0} \mathrm{O}_{6}
$$


When the elements distribution is set, we then calculate the proportions of each element in each given site. We observe that the diopside phase is much more favorable to the incorporation of $\mathrm{Cd}$ than $\mathrm{Pb}$. According to the second Goldschmidt rule [3], the smaller element would be incorporated preferentially because it is expected to form a stronger ionic bond. $\mathrm{Cd}^{2+}$ has its ionic radius (1.10 $\AA$ in coordination 8) close to $\mathrm{Ca}^{2+}(1.12 \AA \AA$ in coordination 8), less than $2 \%$ different while the ionic radius of $\mathrm{Pb}^{2+}(1.29 \AA$ in coordination 8$)$ is $15 \%$ higher than that of $\mathrm{Ca}^{2+}$. This feature could explain the greater incorporation of cadmium. In terms of valence also, the situation is also in favor of an incorporation of $\mathrm{Cd}$ : indeed $\mathrm{Pb}$ could be oxidized in $\mathrm{Pb}^{4+}$, while $\mathrm{Cd}$ has only one oxidation state $(2+)$ similar to that of $\mathrm{Ca}$. Another aspect which is also involved in the substitution mechanism is the electronegativity which is explained by Pauling's scale [20] and by the fourth Goldschmidt rule [3]. It is still more favorable to $\mathrm{Cd}^{2+}$ whose bond energy is closer to that of $\mathrm{Ca}^{2+}\left(\mathrm{E}_{\mathrm{Ca}}=1 ; \mathrm{E}_{\mathrm{Cd}}=1.69 ; \mathrm{E}_{\mathrm{Pb}}=1.8\right)$. According to this conclusion, cadmium has more facility to substitute calcium in a mineral solid solution because its electronegativity is closer.

The black grains (labelled " 3 " on Figure 2) could be attributed to a Cd-bearing forsterite phase $\left[\mathrm{Mg}_{2} \mathrm{SiO}_{4}\right]$ which has been proposed after the XRD analyses described above: this phase could have the following formula $\left(\mathrm{Mg}_{0.99} \mathrm{Cd}_{0.01}\right) \Sigma_{2.0}\left(\mathrm{Si}_{0.98} \mathrm{Al}_{0.02}\right) \Sigma_{1.0} \mathrm{O}_{4}$. The small amount of $\mathrm{Cd}^{2+}$ is proposed to incorporate the $\mathrm{Mg}^{2+}$ site, despite a large difference of ionic radius $\left(\mathrm{Mg}^{2+}: 0,72 \AA\right.$ in coordination $6 ; \mathrm{Cd}^{2+}: 0.95 \AA$ in coordination 6 , then the difference is slightly higher than 30\%). One phase observed by XRD is not detected by EDX analysis: augite $\left[\mathrm{Ca}(\mathrm{Mg}, \mathrm{Ti}, \mathrm{Al})(\mathrm{Si}, \mathrm{Al}) \Sigma_{2.0} \mathrm{O}_{6}\right]$. It is probably a minor phase which could not be detected by SEM in the sample in spite of intense search.

\subsubsection{Sintered ceramics}

The XRD patterns of SC-GS and SC-CdPb are presented in Figure 4. The presence of several phases is confirmed so the samples are clearly poly-crystallized. If we compare the two diffractograms, SC-CdPb has a lower degree of crystallization (highest peak at $\sim 1500$ in intensity) than SC-GS (highest peak at $~ 4000$ in intensity). This result correlates the feature observed in the glass ceramic samples presented above, as the presence of lead and cadmium could limit the crystallization process. 
We were able to assign most of the peaks. From the ASTM database, we could identify five possible phases: armalcolite $\left[\mathrm{MgTi}_{2} \mathrm{O}_{5}\right]$, geikielite $\left[\mathrm{MgTiO} \mathrm{O}_{3}\right]$, hollandite $\left[\mathrm{Ba}_{1.1} \mathrm{Mg}_{1.1} \mathrm{Ti}_{6.9} \mathrm{O}_{16}\right]$, perovskite $\left[\mathrm{BaTiO}_{3}\right]$ and rutile $\left[\mathrm{TiO}_{2}\right]$. Four of them were clearly found in both samples: hollandite, armalcolite, perovskite and rutile. In SC-CdPb sample, the extra phase is proposed to be the geikielite, even if its presence is not excluded in the SC-GS sample. The following transformation involving 3 phases could occur in both samples, perhaps more intensively in the SC-CdPb sample: $\mathrm{MgTi}_{2} \mathrm{O}_{5} \rightarrow \mathrm{MgTiO}_{3}+\mathrm{TiO}_{2}$. We expect that the geikielite phase could have been formed at the expense of the armalcolite phase. One can notice that the addition of heavy metals like $\mathrm{Pb}$ and/or $\mathrm{Cd}$ into the initial mixture could contribute to change the mineralogy of the final sintered ceramic, however with a constant trend in both samples: the major presence of a hollandite-type phase. This major presence of hollandite is evidenced in the SEM image in Figure5, and also in the XRD patterns in Figure 4 which mainly display peaks from hollandite. We also observed additional extra peaks (indicated by *) which could not been assigned.

The SEM investigation of SC-CdPb is presented and summarized in Figure 5 and Table 2. This figure displays several mineral grains. According to the EDX results, the major phase (light grey - analysis spot labelled "1" on Figure 5) may correspond to the hollandite phase with the chemical formula $\left(\mathrm{Ba}_{0.91} \mathrm{~Pb}_{0.09}\right) \Sigma_{1.33} \mathrm{Mg}_{1.33} \mathrm{Ti}_{6.67} \mathrm{O}_{16}$. Hollandite with barium is one of the mineral phases proposed in the SYNROC (SYNthetic ROCK) ceramic where it is evaluated as a good candidate for the sustainable incorporation of radioactive elements [12]. In the SC-CdPb sample, this phase is observed to incorporate $3.12 \mathrm{wt} \% \mathrm{PbO}$ (about $3 \mathrm{wt} \% \mathrm{~Pb}$ ). Note that a similar phase has been observed in the SC-GS sample, with a slightly different chemical formula $\mathrm{Ba}_{1.24} \mathrm{Mg}_{1.29} \mathrm{Ti}_{6.72} \mathrm{O}_{16}$.

Dark grey contrasts correspond to two slightly different compositions. One, marked with the number " 2 " on Figure 5, is composed of a mixture of $\mathrm{MgO}$ and $\mathrm{TiO}_{2}$. The EDX analysis shows that this is likely the armalcolite phase $\left[\mathrm{MgTi}_{2} \mathrm{O}_{5}\right]$, identical to that observed in the green sample (SC-GS). The second grey phase marked with number " 3 " on Figure 5 is very rich in CdO (59 wt\% CdO ; 52 wt\% Cd). If this phase is assumed to be the geikielite phase $\left[\mathrm{MgTiO}_{3}\right]$, the chemical formula would be $\left(\mathrm{Mg}_{0.1} \mathrm{Cd}_{0.9}\right) \mathrm{TiO}_{3}$ (as obtained from EDX microanalysis as shown in Figure 6a). Although the Mg site could be little sized for hosting larger cations like $\mathrm{Cd}^{2+}\left(\mathrm{Cd}^{2+}\right.$ is $37 \%$ larger than $\mathrm{Mg}^{2+}$ in coordination 4), geikielite could be a candidate for a Mg-Cd substitution like for the forsterite phase observed in the glass 
ceramic sample GC-CdPb. The difference in the present $\mathrm{SC}-\mathrm{CdPb}$ sample is the great amount of cadmium which could be incorporated in the Mg site in this geikielite phase (up to about $60 \mathrm{wt} \% \mathrm{CdO}$ in the geikielite, compared to about $1.2 \mathrm{wt} \% \mathrm{CdO}$ in forsterite). On the other hand, no presence of lead is observed in this phase $\left(\mathrm{Pb}^{2+}\right.$ is $72 \%$ larger than $\mathrm{Mg}^{2+}$ when in coordination 4 , then making unlikely a substitution of $\mathrm{Mg}$ by $\mathrm{Pb})$.

The phase with the lightest contrast (labelled "4" on Figure 5) shows the presence of both toxic heavy metals $\mathrm{Pb}$ and $\mathrm{Cd}$. This phase could correspond to a perovskite phase $\left[\mathrm{BaTiO}_{3}\right]$ with a chemical formula of $\left(\mathrm{Ba}_{0.24} \mathrm{~Pb}_{0.73} \mathrm{Cd}_{0.03}\right) \Sigma_{1.0} \mathrm{TiO}_{3}$ (Figure $6 \mathrm{~b}$ ). Like hollandite, this mineral phase is also proposed as a main component in the SYNROC ceramic. In comparison to hollandite, perovskite is more efficient to incorporate lead into its structure. Lead seems to replace a large part of barium while cadmium is present in very small quantities. Higher affinity for lead than for cadmium could be due to the size difference of ionic radii $\left(\mathrm{Ba}^{2+}: 1.57 \AA \AA\right.$ in coordination $12 ; \mathrm{Pb}^{2+}: 1.49 \AA \AA$ in coordination 12 and $\mathrm{Cd}^{2+}: 1.31 \AA$ in coordination 12). Lead is closer to barium with a size difference of only $0.08 \AA(5.1 \%)$, while the size difference of cadmium is $16.6 \%$. The substitution of $\mathrm{Ba}^{2+}$ by $\mathrm{Cd}^{2+}$ would probably lead to stronger distortions of the crystal network and this scenario would be unlikely in terms of energy.

\subsection{Chemical durability}

After the analysis of microstructures and mineralogical and chemical compositions of both types of samples, we performed leaching tests (TCLP tests) to determine and to evaluate the minerals stability and the efficiency of lead and cadmium immobilization. The results from TCLP Leaching Standards for Defined Hazardous Industrial Waste [21] were obtained by ICP-AES. This analysis gives the exact quantity of heavy metals released from the material. For both samples GC-CdPb and SC-CdPb, the results are promising.

\subsubsection{Glass ceramics}

The quantities of trace elements in the leaching solution are given in Table 3. Most of the cadmium keeps incorporated into the GC-CdPb sample because no trace of $\mathrm{Cd}$ is detected in the leachate: $\mathrm{Cd}$ was not detected by the ICP-AES, then far below the TCLP limit of $1 \mathrm{ppm}$ for $\mathrm{Cd}$. The lead was detected in the 
leachate, but only in a concentration of $3.95 \mathrm{ppm}$, which is below the TCLP limit of 5 ppm for Pb which determines hazardousness for environment according to standards promulgated by the U.S. Environmental Protection Agency (USEPA). These results show that the mineral phases observed in the sample GC-CdPb are very promising in terms of immobilization of toxic elements $\mathrm{Pb}$ and $\mathrm{Cd}$.

Figure 7 presents a SEM global view of the GC-CdPb sample after a TCLP acid attack: we observe an alteration about $120 \mu \mathrm{m}$ deep from the surface. Since a standard TCLP leaching test lasts 20 hours, the alteration speed is then about $6 \mu \mathrm{m}$ per hour. Note that the large dark areas present among the sample (see Figure 7), rather correspond to holes probably due to the brittle character of the sample; however, the porosity of the GC-CdPb sample is measured as quite low (about $3.8 \%$ ).

Unlike the altered zone, no change in structure or composition was observed in the underlying non-altered zone. The altered zone as shown in Figure 8, reveals the minor presence of white or light parts (which were more abundant in the non-altered GC-CdPb sample, as shown in Figure 2): these parts were proposed to correspond to the glassy matrix of the glass ceramic, which was shown to be able to incorporate large amounts of $\mathrm{PbO}$ (more than 50 wt\% $\mathrm{PbO}$ and about 3 wt\% $\mathrm{CdO}$; note that we obtain a glass matrix with a PbO content about twice that of a commercial lead-bearing glass called "Crystal"). The EDX chemical analyses display large error bars due to the submicronic size of the white regions in the altered zone. However if we compare the composition of these white parts before and after TCLP, although lead is still remaining after leaching in these parts, EDX analysis detected the important weight loss of the initial lead oxide present: then this glassy matrix would be poorly efficient to immobilize lead, and we can expect that most of the lead detected in the leachate after the ICP-AES analysis comes from this glassy matrix. In spite of contrasted immobilization efficiencies of the mineral phases, the global glass ceramic still retains $\mathrm{Pb}$ and $\mathrm{Cd}$ with amounts in leachates below the TCLP limits. The scenario is different for cadmium, since the cadmium keeps unchanged after leaching. Perhaps the chemical bonds are stronger for $\mathrm{Cd}$ than for $\mathrm{Pb}$ in this possibly amorphous phase.

Except for the compositions of the white parts, we observe similarities into the samples before and after leaching. The three contrasts (grey, black and white) are still observed after leaching (See Figure 8). Nevertheless the boundaries of the grey grains are not as sharp as in the non-leached sample and they appear more difficult to detect, and this feature clearly evidences an alteration of these grains. 
According to their chemical composition, these grey grains correspond to the diopside phase. To check the efficiency of the heavy metals incorporation into diopside, we analyzed these grains in the alteration zone with EDX. While lead clearly remains present, cadmium oxide decreased from 6.22 wt\% to 2.53 wt\% after leaching. Then diopside appears as a good candidate for a sustainable incorporation of $\mathrm{Pb}$ but does not seem to be efficient for retaining $\mathrm{Cd}$. Note that the altered zone is too small compared to the whole sample and then the amount of cadmium released from this zone is very low and is not detected by ICP-AES in the leachate.

The dark grains corresponding to the forsterite phase could be easily identified (see Figure 8). If we look at the change in chemical composition after leaching, the variations are not significant. Although incorporating only small amounts of $\mathrm{Pb}$ and $\mathrm{Cd}$, it is plausible that forsterite is able to incorporate heavy metals in a sustainable way.

\subsubsection{Sintered ceramics}

The sample SC-CdPb was divided into several small parts ( $\sim .5 \mathrm{~mm}$ in diameter) with the objective to increase the contact area with the leaching solution and therefore to enhance the probability of $\mathrm{Pb}$ and Cd release. However ICP-AES analysis (Table 3) reveals that only $0.04 \mathrm{ppm} \mathrm{Pb}$ and $0.06 \mathrm{ppm} \mathrm{Cd}$ were released from the various minerals present in the sample after the acid attack; these values are well below the TCLP limits ( $\mathrm{Pb} \leq 5 \mathrm{ppm} ; \mathrm{Cd} \leq 1 \mathrm{ppm})$.

No damage of the sample SC-CdPb is observed by SEM after the TCLP test. Figure 9 displays a typical area in the altered zone with three different contrasts (compared to Figure 5) of ceramic grains labeled 1, 2 and 3. The phase with a dark grey contrast (labelled " 1 " on Figure 9) has been already seen before as geikielite: this phase was found to contain $59 \mathrm{wt} \% \mathrm{CdO}$ (52 wt\% Cd) (Phase with a grey contrast labeled "3" in Figure 5), with a corresponding chemical formula $\left(\mathrm{Mg}_{0.09} \mathrm{Cd}_{0.91}\right) \mathrm{TiO}_{3}$. After the TCLP test, this phase contains only $11 \mathrm{wt} \% \mathrm{CdO}(9.6 \mathrm{wt} \% \mathrm{Cd})$ as detected by EDX. The chemical formula has changed to $\left(\mathrm{Mg}_{0.89} \mathrm{Cd}_{0.11}\right) \Sigma_{1.0} \mathrm{TiO}_{3}$. The cadmium quantity in this phase was divided almost by 5 . As for glass ceramics, the altered zone is probably too small and the amount of geikielite too low, and then the amount of Cd in the leachate remains well below the TCLP limits since only $0.06 \mathrm{ppm} C \mathrm{~d}$ was detected 
by ICP-AES. But this result clearly shows that the geikielite is not a phase candidate for an efficient immobilization of $\mathrm{Cd}$.

The light grey contrast (labelled " 2 " on Figure 9), which is expected to correspond to the $\mathrm{Pb}$ bearing hollandite phase shows no mass loss of lead. The Ba-based hollandite type phase seems to have the ability to incorporate lead in a sustainable way.

The third phase (labelled " 3 " on Figure 9) has the lightest contrast. It is likely the Pb-rich barium-perovskite. EDX analysis shows a small loss of lead after leaching, with about $85 \%$ of the $\mathrm{PbO}$ present in the perovskite still present after the acid attack. Then the Ba-perovskite shows a relatively high capacity for a long-term $\mathrm{Pb}$ immobilization.

\subsection{Physical properties}

For a complete evaluation of the sustainable immobilization of toxic elements, some important physical properties of the glass ceramic and sintered ceramic samples had to be determined (see Table 4): hardness was measured in the Mohs' scale, while porosity, water absorption and density were determined by the method of Archimedean principle. Some measurements could not be achieved because of small amounts of sample.

The samples density depends on the density of each individual mineral phase and on the sample's porosity. We observe a slight upward trend for density values with the addition of heavy metals due to their high density. Lead has a density around $11 \mathrm{~g} . \mathrm{cm}^{-3}$ and cadmium about 8 g.cm ${ }^{-3}$ while magnesium, aluminium and calcium silicate display densities below $3 \mathrm{~g} . \mathrm{cm}^{-3}$. The densities of the GC-GS sample and the GC-CdPb sample are $2.82 \mathrm{~g} . \mathrm{cm}^{-3}$ and $2.84 \mathrm{~g} . \mathrm{cm}^{-3}$ respectively. The density of the sample $\mathrm{SC}-\mathrm{CdPb}$ with hollandite as major mineral phase is $4.2 \mathrm{~g} \cdot \mathrm{cm}^{-3}$, which is the highest we have observed in this study. When compared with conventional concrete [22], glass ceramics and particularly sintered ceramics are considered as materials with high density.

Porosity is a very important property for construction materials because it may affect the abrasion resistance, specific gravity or the strength of the construction structure. The water absorption characteristic is related to the particle's ability to set in a liquid and is in relation with porosity. The 
porosity and water absorption are also strongly related to the chemical resistance against leaching. It is expected that heavy metals could be leached out easily from porous materials.

For glass ceramic samples, the porosity (GC-GS: $6.95 \%$; GC-CdPb: $3.84 \%$ ) and the water absorption (GC-GS: 2.25\%; GC-CdPb: 1.24\%) are almost twice lower when heavy metals are present. These results are in favor of a sustainable incorporation of heavy metals. Unlike glass ceramics, sintered ceramics have not experienced a liquid state; their porosity is expected to be higher. But the volume of the sintered ceramic samples was too small to allow us to perform porosity measurements.

The Mohs' scale was used to determine the hardness of the samples. For construction materials, no standard requirements are specified in terms of hardness but it can be an useful indicator of potentially mechanical resistance of these materials. Hardness of glass ceramics does not show any relation to the heavy metals addition. Both glass ceramic samples display hardness between those of orthoclase and quartz (6-6.5) in Mohs' scale, which is higher than the values corresponding to ordinary concrete $(3-6[22,23])$. The hardness measured for SC-CdPb (3.5) is significantly lower than the hardness for GC-CdPb (6.5), probably because of the porosity difference.

\section{Discussion}

The vitrification and sintering were carried out at high temperatures with no significant mass loss with the exception of the decarbonation loss. The addition of heavy metals does not change the crystal structures significantly as revealed by the XRD patterns, since no significant shift of XRD peaks was observed for any $\mathrm{Cd}$ and/or Pb-bearing phase.

In spite of $\mathrm{Pb}-\mathrm{Cd}$ addition, we demonstrated the possible synthesis of a glass ceramic with diopside as a dominant phase in both samples of GC-GS and GC-CdPb. The incorporation of cadmium and lead into crystalline structures of different minerals by substitution was explained through differences of ionic size as a function of the coordination number (as described by Shannon [19]). Diopside phase is shown to be able to incorporate relatively large amounts of $\mathrm{Cd}$ and also little of $\mathrm{Pb}$. Another possible substitution for $\mathrm{Cd}^{2+}$ is that of $\mathrm{Mg}^{2+}$. In this case the substitution would only be partial because cation size difference is about $24 \%$. Even if forsterite is a minor phase, it displays a CdO 
incorporation up to $1.2 \mathrm{wt} \%$. While cadmium is mostly immobilized in crystallized phases, lead is mainly incorporated into amorphous phase(s). The amount of $\mathrm{PbO}$ in the glass matrix is about $85 \mathrm{wt} \%$.

In the SC-CdPb sintered ceramic sample, we observed the formation of five mineral phases. The $\mathrm{Pb}-\mathrm{Cd}$ partitioning appears clearly in such sample: some mineral phases are candidates for hosting lead while others preferentially incorporate cadmium. Barium-based hollandite incorporates a small amount of lead (about $3 \mathrm{wt} \% \mathrm{PbO}$ ) probably in the site of barium (because of a cation size difference of only $8 \%$, while the oxidation state is expected to be the same). As it is probably a major phase occupying approximately $60 \%$ of the surface (according to SEM images), and likely with the same proportion in volume, Ba-hollandite thus contains a large quantity of the total amount of lead present in the initial mixture. The same feature is observed for the barium-based perovskite phase which is often in contact with hollandite. This perovskite is shown to display a great capacity for an incorporation of lead, likely in the barium site. We found also a few quantity of $\mathrm{Cd}$ in the perovskite phase which could be a possible host for both heavy metals.

Cadmium is shown to enter the $\mathrm{Mg}^{2+}$ site in the geikielite phase (sample SC-CdPb) but also in a forsterite phase (sample GC-CdPb). The size difference between $\mathrm{Mg}^{2+}$ and $\mathrm{Cd}^{2+}$ could make possible the substitution between these two cations, much easier than for $\mathrm{Pb}^{2+}$ which has a cationic size much larger compared to $\mathrm{Mg}^{2+}$. Note also that three mineral phases of the sintered ceramic SYNROC (hollandite, perovskite and rutile) were synthetized in this study, which give a good perspective for an efficient immobilization of heavy metals as shown for nuclear waste in SYNROC $[24,25]$.

Leaching experiments performed on glass ceramics and sintered ceramics confirm that the heavy metals are well stabilized into most of newly formed phases. The structure of the glass ceramic $\mathrm{GC}-\mathrm{CdPb}$ is expected to be more resistant against an acid attack because of the $\mathrm{Pb}-\mathrm{Cd}$ incorporation into crystals embedded into a glass matrix because it generates a double protection and probably also because of stronger bonds. The analyses realized on GC-CdPb show that the $\mathrm{Cd}$ is more resistant to leaching compared to the $\mathrm{Pb}$ which is incorporated mainly into the amorphous phase. According to the size of $\mathrm{Pb}$ cations, it is more difficult for $\mathrm{Pb}$ to enter into a crystalline network, but when it happens, the energy required for its releasing is too high and $\mathrm{Pb}$ remains sustainably incorporated. The efficiency of lead incorporation against leaching attack was evaluated to $70 \%$ (according to the composition changes 
and the decreasing amount of lead in individual phase analyzed by EDX before and after the leaching tests).

In the case of SC-CdPb, the ICP-AES analysis detected almost no traces of heavy metals. This study demonstrates that the system based on the barium-rich hollandite is sustainable with a simple mineralogical composition and a high efficiency in terms of immobilization of lead and cadmium.

Physical properties and analyses are important for the choice of the part of the construction chain where these materials can be used. It must be emphasized that the physical properties of the glass ceramics and the sintered ceramics presented in this work, are competitive and fully comparable to construction materials like concrete. Both glass and sintered ceramics display greater density, reduced porosity and high hardness especially for glass ceramics corresponding to the hardest concretes. Both types of materials give satisfying and promising results and could have useful applications and perspectives.

We observe a strong decrease of the porosity of the materials studied in this work, related to the addition of heavy metals (lead and cadmium). Then the addition of hazardous $\mathrm{Pb}$-Cd bearing wastes could mechanically strengthen the final material produced with these starting wastes. In parallel, this $\mathrm{Pb}-\mathrm{Cd}$ addition seems to limit the crystallization in both types of materials, glass ceramic and sintered ceramic. This limitation of the crystal nucleation and growth could be due to the incorporation of $\mathrm{Pb}$ and/or Cd into the crystalline phases.

\section{Conclusion}

In this study the possibility of immobilization of selected heavy metals have been demonstrated and constrained for glass ceramics and sintered ceramics in the systems $\mathrm{CaO}-\mathrm{MgO}-\mathrm{SiO}_{2}-\mathrm{Al}_{2} \mathrm{O}_{3}$ and $\mathrm{BaO}-\mathrm{MgO}-$ $\mathrm{TiO}_{2}$ respectively. The immobilization of MSWI ashes into glass ceramic or ceramic matrices could be one of the promising methods to valorize these hazardous wastes.

The glass ceramics and the sintered ceramics give good results in terms of toxic elements incorporation and of chemical and mechanical resistance. Furthermore the results show that a mixture 
of crystalline phases could be a good way to immobilize heavy metals and prevent their release into different components of the environment.

Further research should be focused on the possibility to obtain these materials by mixing commercial oxides with hazardous solid residues like fly ash. Glass ceramics and sintered ceramics production from incinerated raw material could be simple only by adding some oxides like $\mathrm{TiO}_{2}, \mathrm{BaO}$ or $\mathrm{SiO}_{2}$. The important objective is to transform these hazardous wastes produced by incineration, into new materials directly used in the industrial construction domain for example. In the future, such method could solve the issue of hazardous wastes under reasonable economically and environmentally conditions.

\section{Acknowledgements}

The authors want to thank the staff of the Institute of Mineral Resources and Engineering (IMRE) of National Taipei University of Technology (NTUT) in Taiwan.

The authors acknowledge the financial support (BQR) from University Paris-Est Marne-la-Vallée (UPEM), to cover expenses related to the work presented in this paper.

The authors thank Dr. Omar Boudoma (Camparis, Université Pierre et Marie Curie, Paris) for its technical assistance for the SEM observations and analyses. 


\section{References}

[1] Nowak B., Aschenbrenner P. and Winter F.; "Heavy metal removal from sewage sludge ash and municipal solid waste fly ash - A comparison", Fuel processing Technology, 2013, vol. 105, p. 195-201.

[2] Goel A., Tulyaganov D.U., Agathopoulos S., Ribeiro M.J. and Ferreira J.M.F.; "Crystallization behaviour, structure and properties of sintered glasses in the diopside $\beta$ Ca-Tschermak system", J. European Ceramic Society, 2007, vol. 27, no 82, p. 3231-3238.

[3] Burns R.G.; "Mineralogical Applications of Crystal Field Theory”, 2nd edition, Cambridge University Press, 2005, 303 p., ISBN-10: 0521017858.

[4] Hayward P.J.; "The use of glass ceramics for immobilizing high level wastes from nuclear fuel recycling", Glass Technol., 1988, vol. 29, p. 122- 136.

[5] Caurant D., Majerus O., Loiseau P., Bardez I., Baffier N. and Dussossoy J.L.; “Crystallization of neodymium-rich phases in silicate glasses developped for nuclear waste immobilization”, J. Nucl. Mater., 2006, vol., p. 143-162.

[6] Rawlings R.D., Wu J.P. and Boccaccini A.R.; "Glass-ceramics: their production from wastes - a review", J. Mater. Sci., 2006, vol. 41, p. 733- 761.

[7] Cioffi R., Pernice P., Aronne A., Catauro M. and Quattroni G.; “Glass - ceramics from fly ash with added MgO and TiO2", J. European Ceramic Society, 1994, vol. 14, p. 517-552.

[8] Barbieri L., Corradi A., Lancellotti I. and Manfredini T.; "Use of municipal incinerator bottom ash as sintering promoter in industrial ceramics", Waste Management, 2002, vol. 22, p. 859-863.

[9] Qian G., Song Y., Zhang C., Xia Y., H. Zhang and Chui P.; “Diopside-based glass-ceramics from MSW fly ash and bottom ash", Waste Management, 2006, vol. 26, no 12, p. 1462-1467.

[10] Cheng T.W. and Chen Y.S.; "Characterization of 621 glass ceramics made from incinerator fly ash", Ceramics International, 2004, vol. 30, p. 343-349.

[11] Barbieri L., Corradi A., Lancellotti I. and De Oliveira I.; "Nucleation and crystal growth of a MgOCaO-Al2O3-SiO2 glass with added steel fly ash", J. American Ceramic Society, 2002, vol. 85, p. 670-674.

[12] Ringwood A.E., Kesson S.E., Ware N.G., Hibberson W.D. and Major A.; "Immobilization of high level nuclear reactor wastes in SYNROC", Nature, 1979, vol. 278, p. 219-223. 
[13] Kesson S.E.; "The immobilization of Cesium in Synroc Hollandite”, Radioactive Waste Management Nuclear Fuel Cycle, 1983, vol. 2, p. 53-71.

[14] Li L., Luo S., Tang B. and Wang D.; “Immobilization of sodium - bearing high - level radioactive waste in Synroc containing (Na0.5Nd0.5)TiO3 - type perovskite", J. American Ceramic Society, 1997, vol. 80, p. 250-252.

[15] Badev A.; "Matériaux diélectriques à faibles pertes utilisés comme résonateurs et filtres dans les circuits micro-ondes", PhD thesis defended at the University of Toulouse, November 2008, p. 79-84.

[16] Leinekugel Le Cocq Y., Deniard P., Jobic S., Cerny R., Bart F. and Emerich H.; "Synthesis and characterization of hollandite-type material intended for the specific containment of radioactive cesium", Journal of Solid State Chemestry, 2006, vol. 179, p. 3196-3208.

[17] Aubin-Chevaldonnet V., Caurant D., Dannoux A., Gourier D., Charpentier T., Mazerolles L. and Advocat T. ; “Preparation and characterization of $(\mathrm{Ba}, \mathrm{Cs})(\mathrm{M}, \mathrm{Ti}) 8016\left(\mathrm{M}=\mathrm{Al}^{3+}, \mathrm{Fe}^{3+}, \mathrm{Ga}^{3+}, \mathrm{Cr}^{3+}, \mathrm{Sc}^{3+}, \mathrm{Mg}^{2+}\right)$ hollandite ceramics developed for radioactive cesium immobilization", J. Nucl. Mat., 2007, vol. 366, p. 137-160.

[18] Cheary R.W. and Squadrito R.; "A structural analysis of barium magnesium hollandites”, Acta Cryst., 1989, vol. B45, p. 205-212.

[19] Shannon R.D.; "Revised effective ionic radii and systematic studies of interatomic distances in halides and chalcogenides", Acta Crystallographica, 1976, vol. 32, no 5, p. 751-767.

[20] Pauling L.; "The nature of the chemical bond. IV. The energy of single bonds and the relative electronegativity of atoms", Journal of the American Chemical Society, 1932, vol. 54, p. 3570-3582.

[21] TCLP: Toxicity Characteristic Leaching Procedure : Leaching Standards, Standards for Defining Hazardous Industrial Waste, promulgated by EPA (Environmental Protection Agency) Order (90), No. 00113926, Huan-Shu- Fei-Tzu, 2001.

[22] Dorf R.C.; The Engineering Handbook, 2nd edition, CRC Press, 2004, 3080 p., ISBN-10: 0849315867.

[23] Mk Diamond 644 Products, Inc.: “Understanding Materials: Concrete, California, n.d., retrieved on 4.10.2011 from < http://www. mkdiamond. com/concrete/tec_con.html>.

[24] Smith K.L., Lumpkin G.R., Blackford M.G., Day R.A. and Hart K.P.; “The durability of Synroc”, J. Nucl. Mat. , 1992, vol. 190, p. 287-294. 
[25] Zhang Y., Hart K.P., Bourcier W.L., Day R.A., Colella M., Thomas B., Aly Z. and Jostssons A.; “Kinetics of uranium release from Synroc phases”, J. Nucl. Mat., 2001, vol. 289, p. 254-263. 


\section{Tables}

Table.1. Chemical compositions and heat treatment of individual samples

GC : Glass-ceramic; GS : Green sample; SC : Sintered ceramic

\begin{tabular}{|c|c|c|c|}
\hline \multicolumn{2}{|c|}{ Chemical composition (wt\%) } & \multicolumn{2}{|c|}{ Heat- treatment } \\
\hline \multicolumn{4}{|c|}{ Glass-ceramic } \\
\hline & & VITRIFICATION & DEVITRIFICATION \\
\hline GC-GS & $\begin{array}{l}54 \mathrm{SiO}_{2} ; 9,2 \\
\mathrm{Al}_{2} \mathrm{O}_{3} ; \\
12.3 \mathrm{CaO} ; 24.5 \\
\mathrm{MgO}\end{array}$ & $900^{\circ} \mathrm{C}-60 \mathrm{~min}$ & \multirow{2}{*}{$1050^{\circ} \mathrm{C}-120 \mathrm{~min}$} \\
\hline GC-CdPb & $\begin{array}{l}41 \mathrm{SiO}_{2} ; 7 \\
\mathrm{Al}_{2} \mathrm{O}_{3} ; \\
9.3 \mathrm{CaO} ; 18.6 \\
\mathrm{MgO} ; 12 \mathrm{CdO} ; \\
12 \mathrm{PbO}\end{array}$ & $1500^{\circ} \mathrm{C}-60 \mathrm{~min}$ & \\
\hline \multicolumn{4}{|c|}{ Sintered ceramic } \\
\hline SC-GS & $\begin{array}{l}66 \mathrm{TiO}_{2} ; 26 \\
\mathrm{BaO} ; 8 \mathrm{MgO}\end{array}$ & \multirow{2}{*}{\multicolumn{2}{|c|}{$1380^{\circ} \mathrm{C}-180 \mathrm{~min}$}} \\
\hline $\mathrm{SC}-\mathrm{CdPb}$ & $\begin{array}{l}50 \mathrm{TiO}_{2} ; 20 \\
\mathrm{BaO} ; 6 \mathrm{MgO} ; 12 \\
\mathrm{CdO} ; 12 \mathrm{PbO}\end{array}$ & & \\
\hline
\end{tabular}


Table.2. Chemical composition of individual phases observed by EDX (Wt\%)

\begin{tabular}{|c|c|c|c|c|c|c|c|c|c|c|c|c|c|}
\hline \multirow[t]{2}{*}{ Sample } & \multirow[t]{2}{*}{ Structure } & \multicolumn{12}{|c|}{ Oxides and elements (wt\%) } \\
\hline & & $\mathrm{SiO}_{2}$ & $\mathrm{Si}$ & $\mathrm{Al}_{2} \mathrm{O}_{3}$ & Al & $\mathrm{CaO}$ & $\mathrm{Ca}$ & $\mathrm{MgO}$ & $\mathrm{Mg}$ & $\mathrm{CdO}$ & $\mathrm{Cd}$ & $\mathrm{PbO}$ & $\mathrm{Pb}$ \\
\hline \multirow{2}{*}{ GC-GS } & $\begin{array}{c}\text { Diopside } \\
\left(\mathrm{Ca}_{0.42} \mathrm{Mg}_{0.44} \mathrm{Al}_{0,14}\right)_{1.0} \mathrm{Mg}\left(\mathrm{Si}_{0.88} \mathrm{Al}_{0.12}\right)_{2.0} \mathrm{O}_{6}\end{array}$ & 51.22 & 23.94 & 9.46 & 5.01 & 11.29 & 8.07 & 28.02 & 16.90 & & & & \\
\hline & $\begin{array}{c}\text { Wollastonite } \\
\left(\mathrm{Ca}_{0.31} \mathrm{Mg}_{0.54} \mathrm{Al}_{0.15}\right)_{1.0}\left(\mathrm{Si}_{0.92} \mathrm{Al}_{0.08}\right)_{1.0} \mathrm{O}_{6}\end{array}$ & 52.49 & 24.54 & 10.09 & 5.34 & 16.72 & 11.95 & 20.70 & 12.48 & & & & \\
\hline \multirow{7}{*}{$\begin{array}{l}\text { GC- } \\
\mathrm{CdPb}\end{array}$} & $\begin{array}{c}\text { Diopside "2" on Fig.2 } \\
\left(\mathrm{Ca}_{0.69} \mathrm{Cd}_{0.1} \mathrm{~Pb}_{0.02} \mathrm{Mg}_{0.1} \mathrm{Al}_{0.09}\right)_{1.0} \mathrm{Mg}\left(\mathrm{Si}_{0.92} \mathrm{Al}_{0.08}\right)_{2.0} \mathrm{O}_{6}\end{array}$ & 49.23 & 23.01 & 5.88 & 3.11 & 17.09 & 12.21 & 19.81 & 11.94 & 6.22 & 5.44 & 1.77 & 1.64 \\
\hline & Diopside after leaching on Fig.7 & 42.33 & 19.79 & 20.12 & 10.65 & 12.59 & 9.00 & 16.00 & 9.65 & 2.53 & 2.22 & 6.36 & 5.90 \\
\hline & Forsterite " 3 " on Fig.2 & \multirow{2}{*}{40.40} & \multirow{2}{*}{18.88} & \multirow{2}{*}{0.57} & \multirow{2}{*}{0.30} & \multirow{2}{*}{0.76} & \multirow{2}{*}{0.54} & \multirow{2}{*}{56.68} & \multirow{2}{*}{34.18} & \multirow{2}{*}{1.19} & \multirow{2}{*}{1.04} & \multirow{2}{*}{0.40} & \multirow{2}{*}{0.37} \\
\hline & $\left(\mathrm{Mg}_{0.99} \mathrm{Cd}_{0.01}\right)_{2.0}\left(\mathrm{Si}_{0.98} \mathrm{Al}_{0.02}\right)_{1.0} \mathrm{O}_{4}$ & & & & & & & & & & & & \\
\hline & Forsterite after leaching on Fig.7 & 40.90 & 19.12 & 2.40 & 1.27 & 3.13 & 2.24 & 51.01 & 30.76 & 1.52 & 1.33 & 1.03 & 0.96 \\
\hline & Glass "1" on Fig.2 & 31.91 & 14.92 & 8.84 & 4.68 & 1.88 & 1.34 & 1.72 & 1.04 & 3.23 & 2.82 & 52.43 & 48.67 \\
\hline & Glass after leaching on Fig.7 & 37.01 & 17.30 & 6.16 & 3.26 & 5.84 & 4.17 & 14.62 & 8.82 & 4.93 & 4.31 & 31.34 & 29.09 \\
\hline & & $\mathrm{MgO}$ & $\mathrm{Mg}$ & $\mathrm{TiO}_{2}$ & $\mathrm{Ti}$ & $\mathrm{BaO}$ & $\mathrm{Ba}$ & $\mathrm{CdO}$ & $\mathrm{Cd}$ & $\mathrm{PbO}$ & $\mathrm{Pb}$ & & \\
\hline \multirow{2}{*}{ SC-GS } & $\begin{array}{l}\text { Armalcolite } \\
\mathrm{MgTi}_{2} \mathrm{O}_{5}\end{array}$ & 19.56 & 11.80 & 79.89 & 47.89 & 0.55 & 0.49 & & & & & & \\
\hline & $\begin{array}{c}\text { Hollandite } \\
\mathrm{Ba}_{1.2} \mathrm{Mg}_{1.3} \mathrm{Ti}_{6.7} \mathrm{O}_{16}\end{array}$ & 6.63 & 4.00 & 68.90 & 41.32 & 24.27 & 21.86 & & & & & & \\
\hline \multirow{6}{*}{$\begin{array}{l}\text { SC- } \\
\mathrm{CdPb}\end{array}$} & $\begin{array}{l}\text { Armalcolite "2" on Fig.5 } \\
\qquad \mathrm{MgTi}_{2} \mathrm{O}_{5}\end{array}$ & 19.73 & 11.90 & 80.13 & 48.03 & & & 0.15 & 0.13 & & & & \\
\hline & $\begin{array}{l}\text { Geikielite "3" on Fig.5 } \\
\left(\mathrm{Mg}_{0.1} \mathrm{Cd}_{0.9}\right)_{1.0} \mathrm{TiO}_{3}\end{array}$ & 1.71 & 1.03 & 39.18 & 23.49 & & & 59.10 & 51.74 & & & & \\
\hline & Geikielite after leaching "1" on Fig.9 & 27.53 & 16.60 & 61.49 & 36.86 & & & 10.98 & 9.61 & & & & \\
\hline & $\begin{array}{c}\text { Hollandite " } 1 \text { " on Fig.5 } \\
\left(\mathrm{Ba}_{0.91} \mathrm{~Pb}_{0.09}\right)_{1.33} \mathrm{Mg}_{1.33} \mathrm{Ti}_{6.67} \mathrm{O}_{16}\end{array}$ & 7.11 & 4.29 & 67.09 & 40.22 & 22.68 & 20.31 & 0.01 & 0.01 & 3.12 & 2.89 & & \\
\hline & Hollandite after leaching "2" on Fig.9 & 6.89 & 4.16 & 66.06 & 39.59 & 23.15 & 20.73 & 0 & 0 & 3.90 & 3.63 & & \\
\hline & $\begin{array}{l}\text { Perovskite " } 4 \text { " on Fig.5 } \\
\left(\mathrm{Ba}_{0.24} \mathrm{~Pb}_{0.73} \mathrm{Cd}_{0.03}\right)_{1.0} \mathrm{TiO}_{3}\end{array}$ & 0.11 & 0.07 & 28.12 & 16.85 & 12.79 & 11.46 & 1.40 & 1.22 & 57.59 & 53.46 & & \\
\hline & Perovskite after leaching " 3 " on Fig.9 & 0 & 0 & 31.35 & 18.95 & 17.01 & 15.23 & 0.78 & 0.68 & 49.43 & 46.85 & & \\
\hline
\end{tabular}


Table.3 . TCLP results analyzed by ICP-AES (ppm)

N.D.: Non-detected

\begin{tabular}{|c|c|c|}
\hline Sample & Cd & Pb \\
\hline Fly ash & 24.4 & 19.6 \\
\hline GC-CdPb & N.D. & 3.95 \\
\hline SC-CdPb & 0.06 & 0.04 \\
\hline TCLP Limits & 1 & 5 \\
\hline
\end{tabular}


Table.4 . Physical properties

N.M.: Not Measured (Some measurements could not be achieved because of small amounts of sample)

\begin{tabular}{|c|c|c|c|c|}
\hline Sample & $\begin{array}{c}\text { Specific gravity } \\
\left(\mathbf{g} / \mathrm{cm}^{3} \text { ) }\right.\end{array}$ & Porosity (\%) & $\begin{array}{c}\text { Water } \\
\text { absorption (\%) }\end{array}$ & $\begin{array}{c}\text { Hardness } \\
\text { (Mohs' scale) }\end{array}$ \\
\hline GC-GS & 2.82 & 6.95 & 2.25 & 6 \\
\hline GC-CdPb & 2.84 & 3.84 & 1.24 & 6.5 \\
\hline SC-GS & N.M. & N.M. & N.M. & N.M. \\
\hline SC-CdPb & 4.2 & N.M. & N.M. & 3.5 \\
\hline
\end{tabular}




\section{Figure Captions}

Figure 1. X-ray diffraction (XRD) patterns of GC-GS and GC-CdPb.

The Bragg peaks could be assigned to the following minerals: An (Anorthite), Au (Augite), D (Diopside), F (Forsterite), W (Wollastonite).

Figure 2. Backscattered electron SEM image of the GC-CdPb sample.

1: White area (amorphous matrix); 2: Grey area (diopside phase); 3: Black grains (forsterite phase)

Figure 3. EDX spectrum and analysis of the grey phase (labelled "2" on Figure 2).

Figure 4. X-ray diffraction (XRD) patterns of SC-GS and SC-CdPb.

The Bragg peaks could be attributed to the following minerals: Ar (Armalcolite), Ge (Geikielite), Ho (Hollandite), P (Perovskite), R (Rutile); *: extra peaks which could not been assigned

Figure 5. Backscattered electron SEM image of the SC-CdPb sample.

1: The light grey area (hollandite phase); 2: The grey area (armalcolite phase); 3: The grey area (geikielite phase); 4: The white area (perovskite phase)

Figure 6. EDX spectra: a) grey contrast (labelled “3"/geikielite phase on Figure 5); b) lightest contrast (labelled "4"/ perovskite phase on Figure 5).

Figure 7. Backscattered electron SEM image of the GC-CdPb sample. after leaching test (altered zone with 120 microns depth).

We see large dark zones corresponding to holes probably due to the brittle character of the sample. Note that the samples were cut after leaching in order to see a section of the sample and to distinguish the surface (above on the image) and the bulk (below on the image) of the sample. 
Figure 8. Backscattered electron SEM image of the GC-CdPb sample in the altered zone after leaching test.

Figure 9. Backscattered electron SEM image of the SC-CdPb sample in the altered zone after leaching test. 1: The dark grey area (geikielite phase); 2 : The grey area (hollandite phase); $3:$ The light grey area (perovskite phase) 


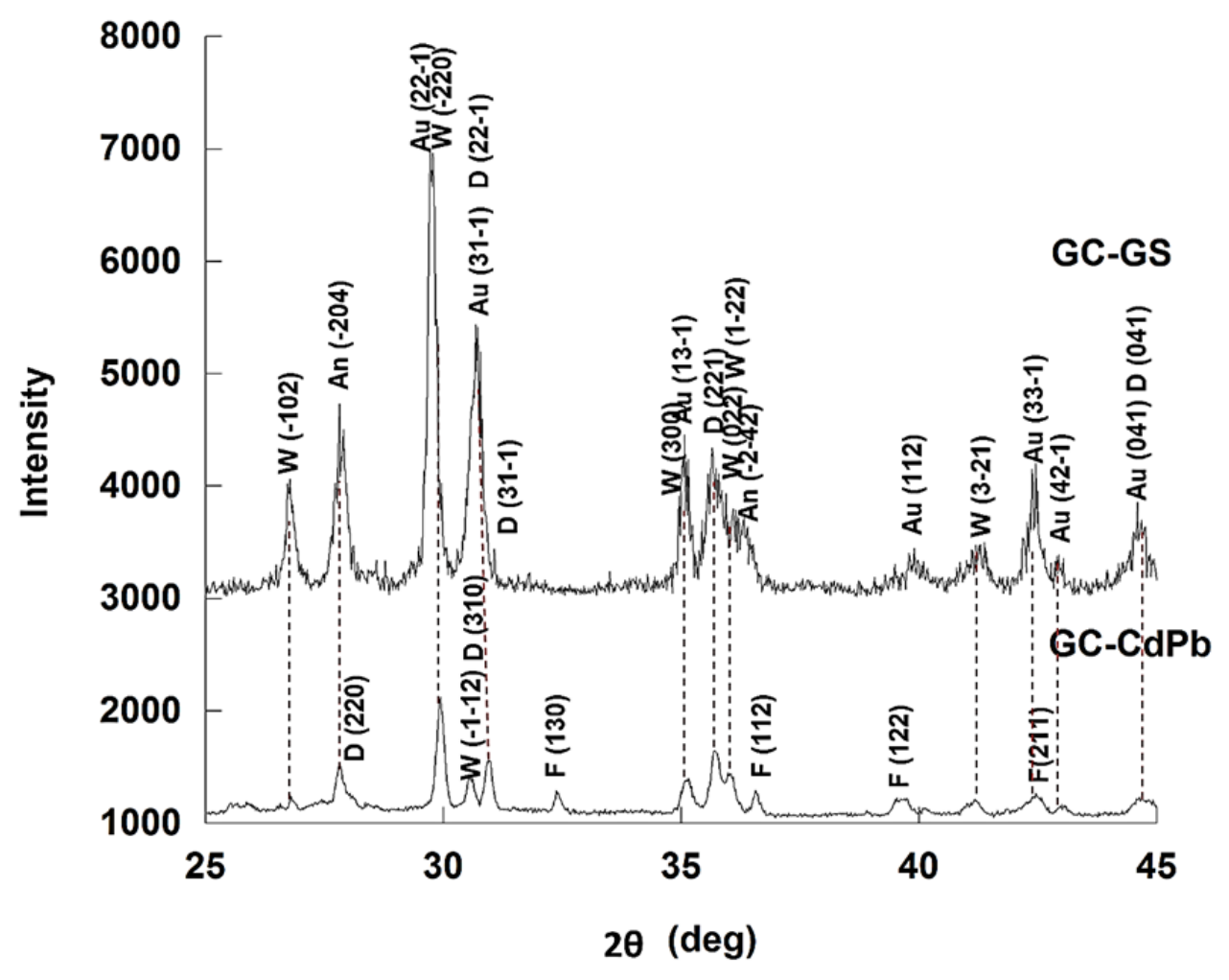

Figure 1 


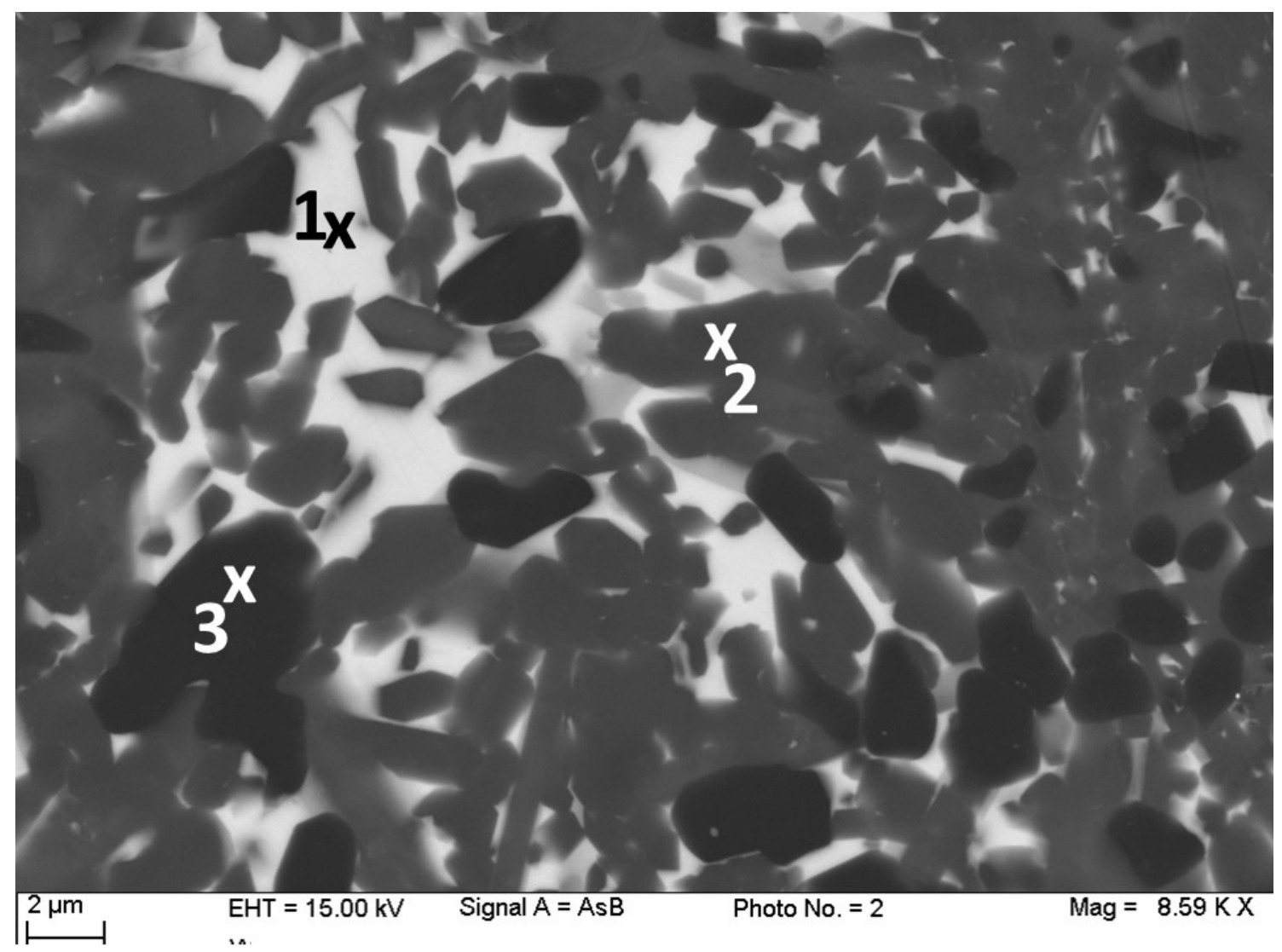

Figure 2 


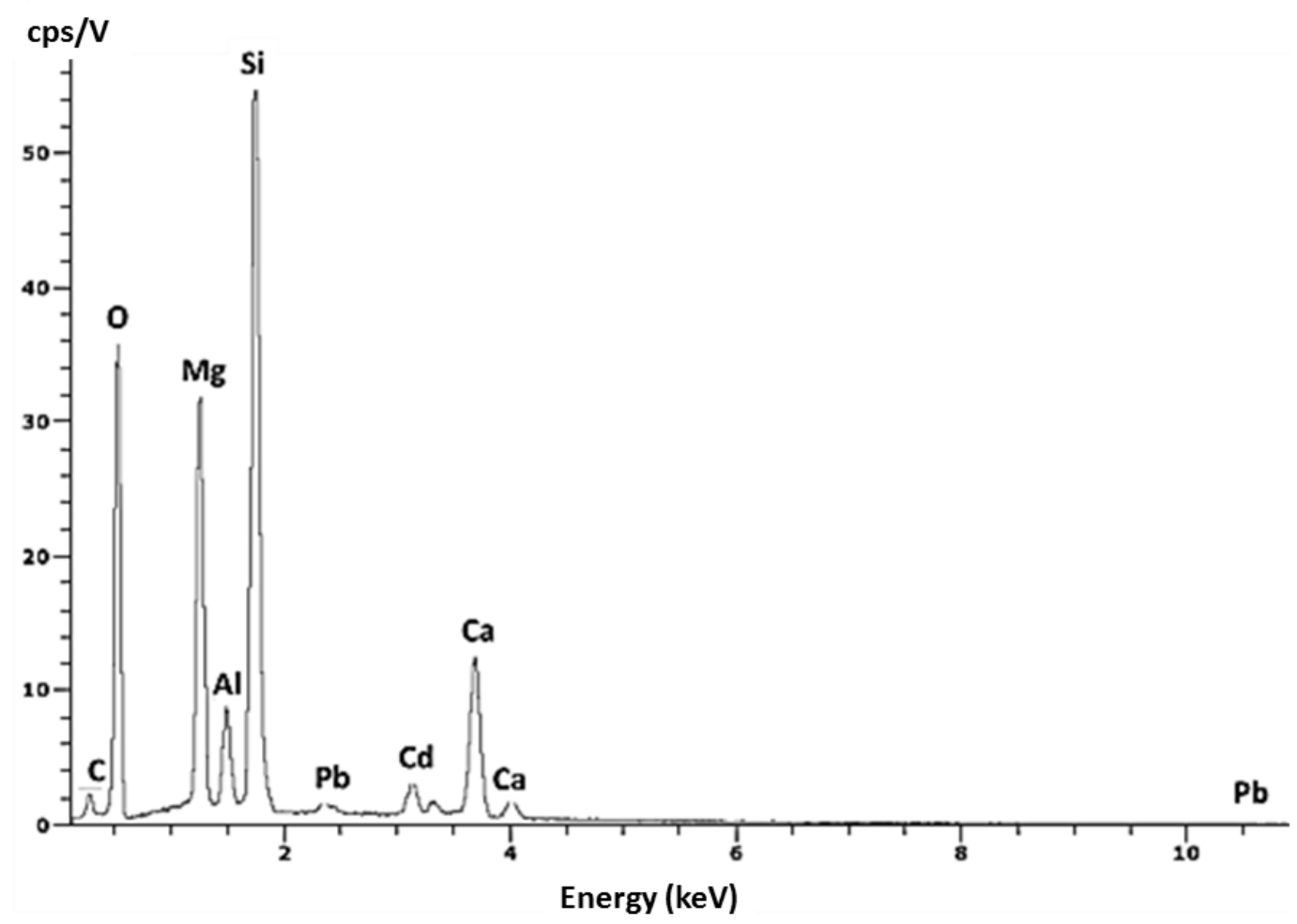

\begin{tabular}{|c|c|c|c|c|c|}
\hline Element & Series & $\begin{array}{c}\text { norm. C } \\
{[w t . s]}\end{array}$ & $\begin{array}{l}\text { stom. C } \\
\text { [at. } \%]\end{array}$ & Compound norm. & $\begin{array}{c}\text { Comp. C } \\
\text { [wt. } 3]\end{array}$ \\
\hline calcium & K-series & 12.21 & 6.84 & $\mathrm{CaO}$ & 17.09 \\
\hline oxygène & $\mathrm{K}$-series & 42.63 & 59.85 & & 0.00 \\
\hline silicium & K-series & 23.01 & 18.41 & SiO2 & 49.23 \\
\hline carbone & K-series & 0.00 & 0.00 & & 0.00 \\
\hline magnésium & K-series & 11.94 & 11.04 & MgO & 19.81 \\
\hline aluminium & $\mathrm{K}$-series & 3.11 & 2.59 & A 1203 & 5.88 \\
\hline p lomb & M-series & 1.64 & 0.18 & $\mathrm{PbO}$ & 1.77 \\
\hline cadmium & L-series & 5.44 & 1.09 & $\mathrm{CdO}$ & 6.22 \\
\hline
\end{tabular}

\section{Figure 3}




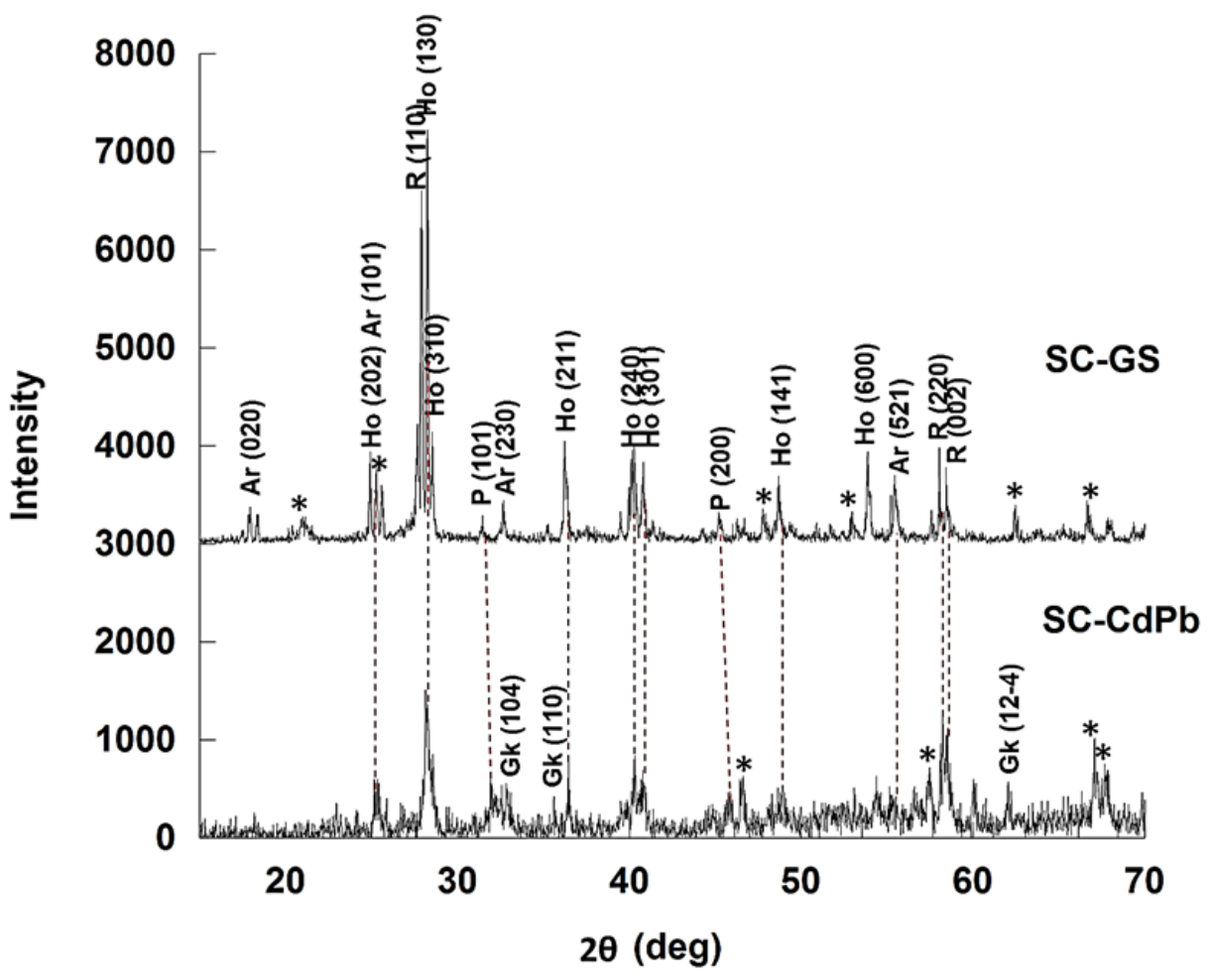

Figure 4 


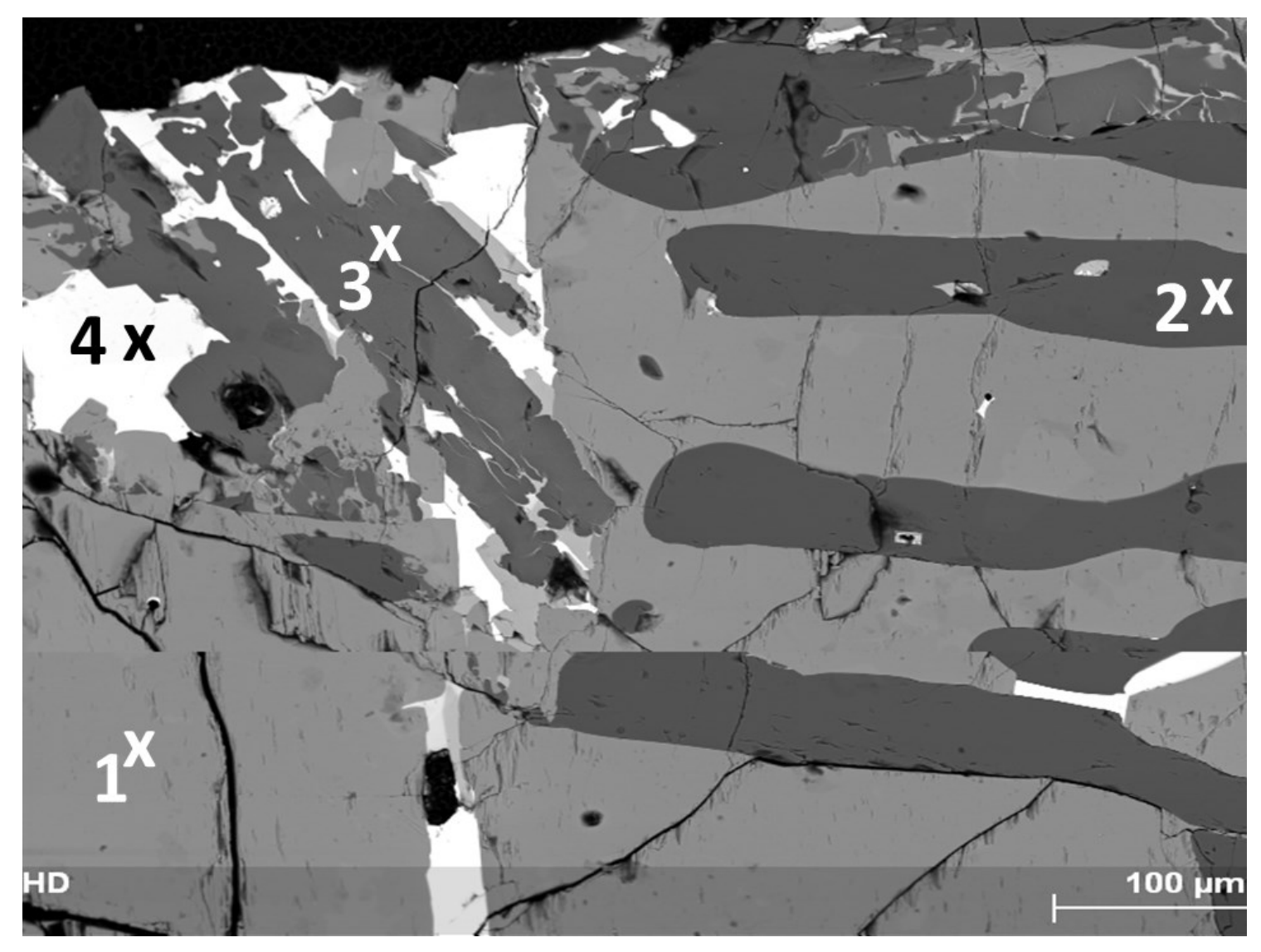

Figure 5 


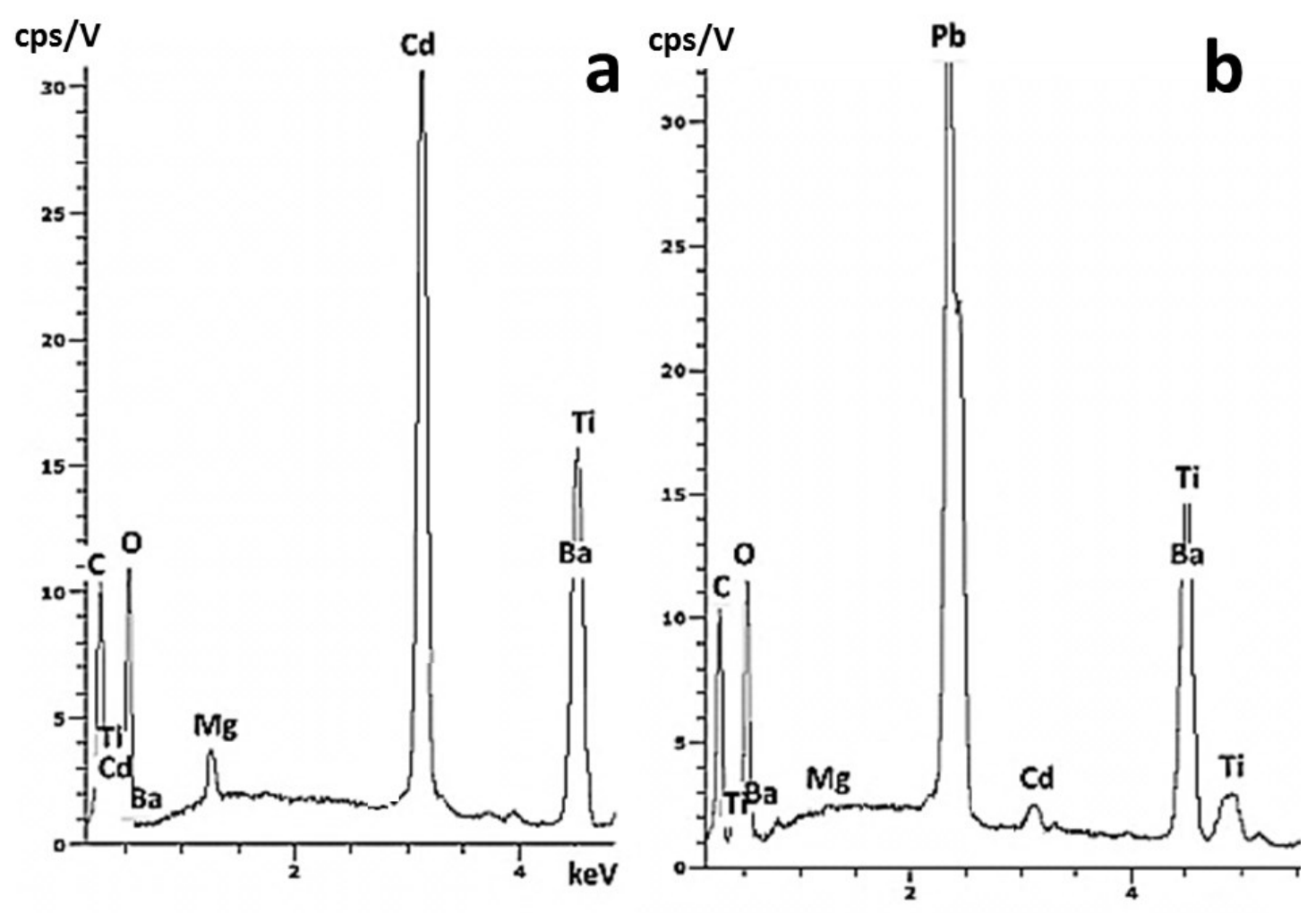

Energv (keV)

\begin{tabular}{|c|c|c|c|c|c|c|c|c|c|c|c|}
\hline & & & & & & Element & Series & $\begin{array}{r}\text { norm. C } \\
{[\mathrm{wt} . \mathrm{t}]}\end{array}$ & $\begin{array}{r}\text { atom. C } \\
\left.\text { [at. } \frac{2}{8}\right]\end{array}$ & Compound norm. & $\begin{array}{l}\text { Comp. } \\
\text { [wt.* }]\end{array}$ \\
\hline Element & Series & $\begin{array}{r}\text { norm. C } \\
{\left[\mathrm{wt} \cdot \frac{*}{*}\right]}\end{array}$ & $\begin{array}{r}\text { Atom. C } \\
\left.\text { [at. } \frac{2}{8}\right]\end{array}$ & Compound norm. & $\begin{array}{l}\text { Comp. C } \\
{\left[\mathrm{wt} .{ }^{*} \mathrm{z}\right]}\end{array}$ & oxygène & K-series & 16.94 & 59.97 & & 0.00 \\
\hline cadmium & L-series & 51.74 & 18.58 & & 59.10 & carbone & K-series & 0.00 & 0.00 & & 0.00 \\
\hline titane & K-series & $\begin{array}{l}51.14 \\
23.49\end{array}$ & $\begin{array}{l}18.58 \\
19.80\end{array}$ & $\mathrm{TiO}$ & 39.18 & magnésium & K-series & 0.07 & 0.15 & Mgo & 0.11 \\
\hline oxygène & $\mathrm{K}$-series & 23.74 & 59.90 & & 0.00 & titane & K-series & 16.85 & 19.93 & $\mathrm{TiO} 2$ & 28.12 \\
\hline carbone & $\mathrm{K}$-series & 0.00 & 0.00 & & 0.00 & baryum & L-series & 11.46 & 4.72 & $\mathrm{BaO}$ & 12.79 \\
\hline magnésium & $\mathrm{K}$-series & 1.03 & 1.72 & $\mathrm{MgO}$ & 1.71 & plomb & M-series & 53.46 & 14.61 & $\mathrm{PbO}$ & 57.59 \\
\hline baryum & L-series & 0.00 & 0.00 & $\mathrm{BaO}$ & 0.00 & cadmium & L-series & 1.22 & 0.62 & Cdo & 1.40 \\
\hline
\end{tabular}

Figure 6 


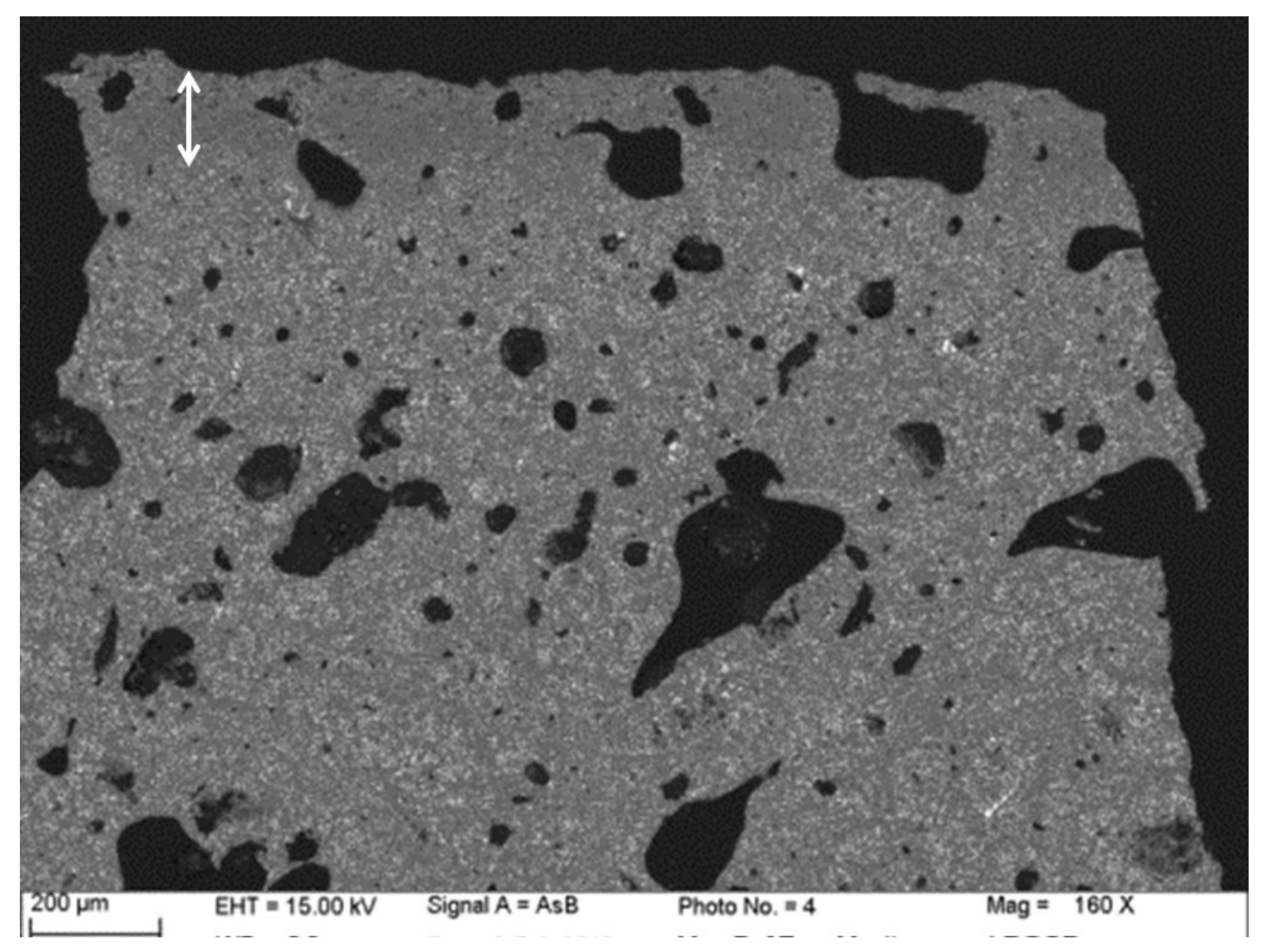

Figure 7 


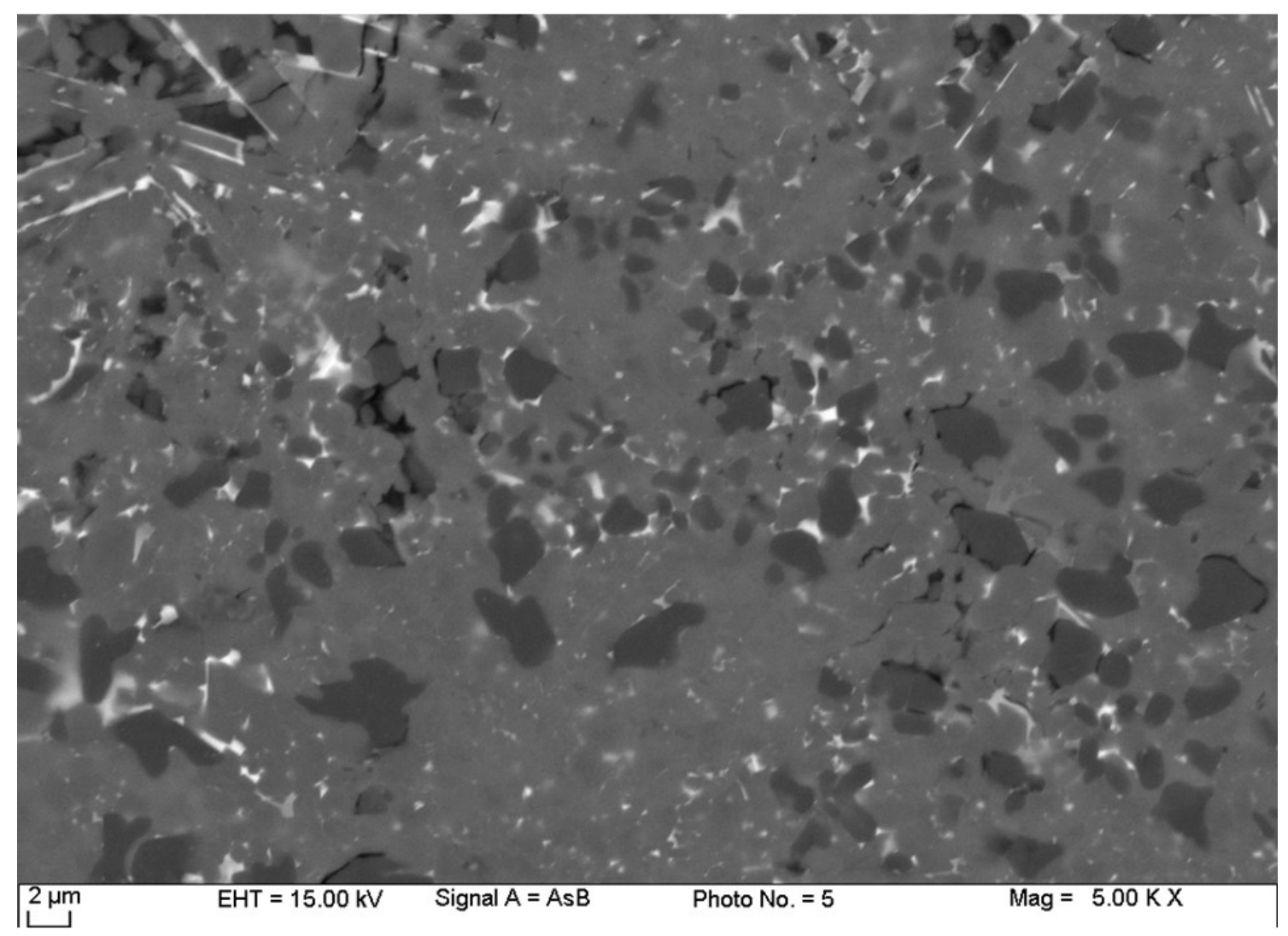

Figure 8 


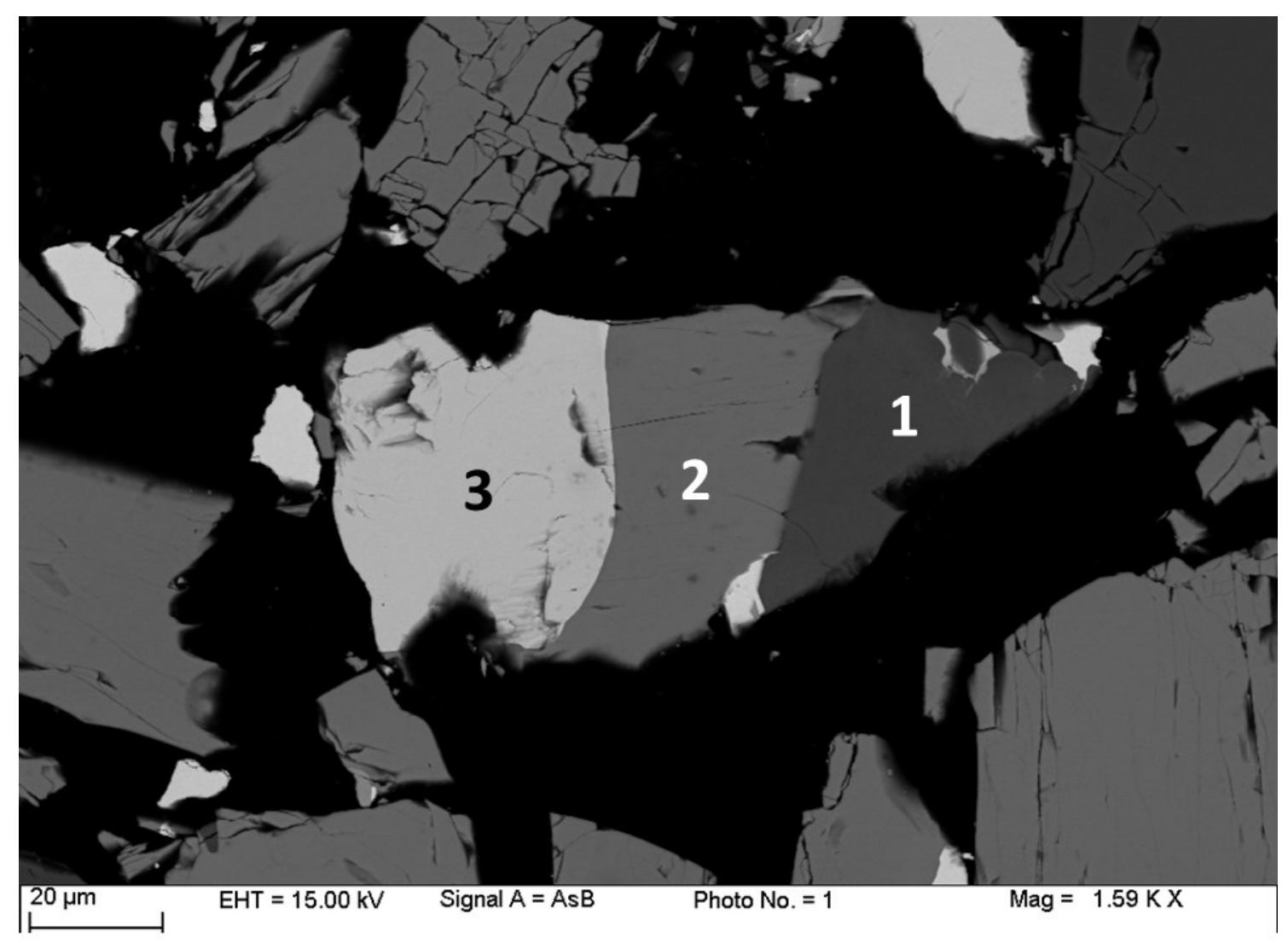

Figure 9 